\title{
ASSESSMENT OF DEMAND FOR PUBLIC GOODS IN THE NON-MARKET SERVICES SECTOR
}

Petrushenko Yuriy, Doctor of Economics, Head of the International Economic Relations

Department, Sumy State University,

57 Petropavlivska Str., Sumy, 40000, Ukraine

Mayboroda Tetyana, Ph.D. in Economics, Assistant of the Management Department

Sumy State University, 2 Rymskoho-Korsakova st., Sumy, 40007, Ukraine

Onopriyeko Kateryna, Ph.D. student of the International Economic Relations Department Sumy State University,

57 Petropavlivska Srt., Sumy, 40000, Ukraine

The article is devoted to the development and approbation of approaches to the assessment of demand for public goods. It presents the results of the assessment of demand for civic education as a public good of the nonmarket services sector. The assessment is based on the application of various research methods: desk research (analysis of publications, reviews, reports), qualitative research (focus groups, in-depth interviews), quantitative research (sociological survey). In this article is carried out the analysis of scientific publications devoted to the analysis of demand for public goods, and the actual aspects of researches are allocated.

The object of research is the process of forming and meeting the demand for civic education. For analysis of the market of educational needs was conducted a comparison of the population's requests for educational services and data of the number of activities carried out by providers of educational services.

The result of research is the proof of hypotheses about low demand for civic education in the conditions of absence of high level of civic competence and in the conditions of mismatch of supply and demand in the field of civic education.

Regarding various areas of civic education, the results of the analysis showed that the greatest demand is in creative studios, and this demand is quite satisfied. Next in the ranking are educational services in the field of leadership and personal development, but these needs are satisfied with less than half. The rest of the needs are unmet, and at the same time we see that due to the actions of service providers, the interest of citizens in political or civic education is approaching to satisfaction level. At the same time, low satisfaction of the needs in financial literacy, critical thinking, and media literacy indicates the necessity to develop and offer educational services of this type. Demand for family psychology, relationship psychology, public speaking and business education is also unmet.

The conclusions of the study formulate proposals for matching demand and supply for civic education through non-market mechanisms. In particular, it is justified the need for the formation of effective demand from local authorities and local public institutions (local schools, universities, businesses, NGOs).

Key words: public goods, non-market services, demand, supply, civic education.

It presents the results of the assessment of demand for civic education as a public good of the non-market services sector. The assessment is based on the application of various research methods: desk research (analysis of publications, reviews, reports), qualitative research (focus groups, in-depth interviews), quantitative research (sociological survey). The result of research is the proof of hypotheses about low demand for civic education in the conditions of absence of high level of civic competence and in the conditions of mismatch of supply and demand in the field of civic education. The conclusions of the study formulate proposals for matching demand and supply for civic education through non-market mechanisms.

Keywords: public goods, non-market services, demand, supply, civic education.

DOI: $10.21272 / 1817-9215.2020 .1-13$

\section{PROBLEM SETTING}

In modern world the quality of local communities life is increasingly dependent not only on the effectiveness of market mechanisms, but also on the efficiency of public goods production which are necessary for local development. Public goods production is also focused on meeting the existing demand, but the mechanisms of demand formation in the non-market sector are different from the formation of market demand. The subject of such demand is often not the consumers of these services, but local authorities, whose task is to ensure the interests realization of the local community. Accordingly, arises the question of the correct assessment of demand for public goods in order to effectively use public funds for their production. 


\section{ANALYSIS OF THE RECENT RESEARCH AND PUBLICATIONS}

Public goods are goods that meet the needs of all members of society equally (national defense, education, public order protection, social guarantees, research, environmental measures, etc.). The characteristic feature of public goods is territorial boundaries of their consumption. In essence, it is necessary to find the community that consumes this good. The borders of this community may not coincide with the boundaries of the society that finances and provides this good. From the point of view of differentiation of consumption limits and provision limits it is distinguished international, national (state) and local public (social) goods.

Local public goods we understand any public goods and services access to which doesn't have the entire population of the country, but only a certain geographical part (several regions, one region, a city, a district, etc., but most often - a territorial community). An example can be certain educational services demaned by a community (including civic education, which consists in mastering the competencies of successful life in the community).

The ideas of the need for state care of production and provision of socially important goods and services both for society in general and at the level of territorial communities originate in the works of representatives of the German school of political economy in the late XIX century. (K. Menger, A. Schaffle, K. Schmidt). Scientists insisted that a group of individuals is able to generate specific goals (to form collective needs) different from individual interests, in that number regarding certain goods (social motivation of the institution of guardianship). Their followers and authors of the Theory of Economic Sociodynamics R. Greenberg and O. Rubinstein had noted in their studies, that in order for a product or service to fall under state care, it is necessary and sufficient for them to have social unsefulness [Помилка! Джерело посилання не знайдено.].

Public good is one of the cases of market imperfection, when state intervention is necessary. Many economists, however, disagreed that government intervention was needed only in a situation with pure (or close to pure) public goods. This is not about government regulation, which affects in practice many industries and different categories of goods, but about the theoretical justification of the range of its application. One of such attempts was the theory of merit goods, put forward by R. Musgrave in the middle of the XX century [3].

In the case of public goods, state intervention is necessary due to the inability of the market to ensure the allocation of resources in accordance with individual preferences, which involves the observancy of consumer's sovereignty. In contrast to this, merit goods represent the case, when individual preferences are no longer considered to be given, but themselves are the subject to adjustment. Merit goods meet the needs which society considers as necessary to support and which are not properly formed with individuals, mainly due to incomplete awareness, but also due to the fact that "we are lazy and not interesting enough." As a result, individuals choose to consume less of these goods than they should. Examples include free education, school lunches and breakfasts, theaters and concert halls, and subsidized housing for low-income families. Meritorious goods, according to O.V. Dlugopolsky, are the subsystem of public goods [2].

Since real demand for public goods cannot be effectively assessed by the market through market pricing, then public goods are usually produced in the non-market sector and a state or local communities take care of their production. At the same time, for the needs of production and distribution this does not eliminate the need to assess the demand for these goods. On the contrary, it even makes this task more difficult.

Not many works of scientists are devoted to the assessment of the demand for public goods in the non-market services sector. Thus, in the period from 1971 to 2019 in the scientometric database Scopus has been found only 77 scientific papers with the keywords "demand for public goods".

Analysis of scientific works of the Scopus scientometric database with the keywords "demand for public goods" shows that the largest number of scientific papers is written in 
the field of economics (48.8\%), in second place are social sciences with the indicator $28.9 \%$ and third place is shared by business sciences and environmental sciences by $5 \%$ (Fig.1).

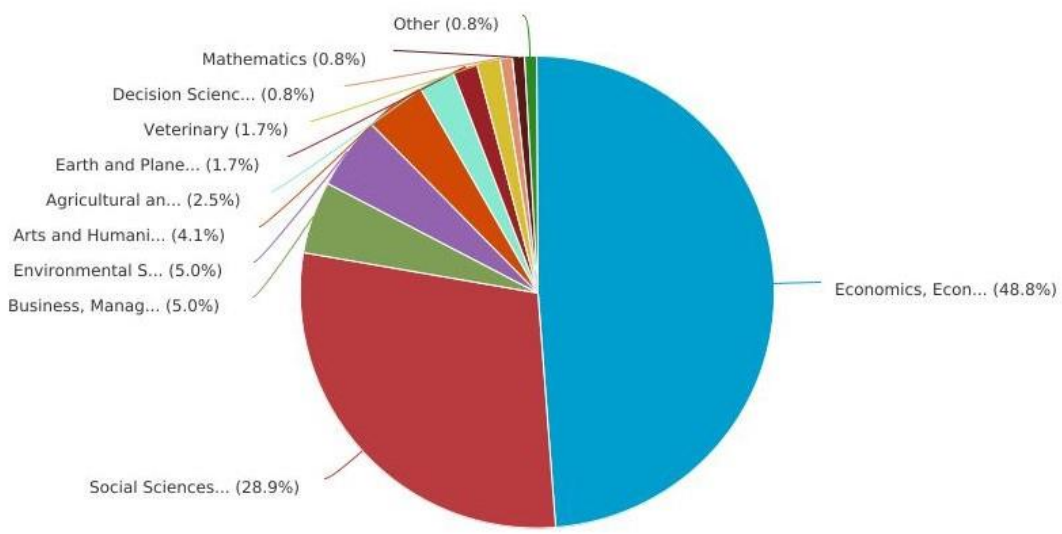

Figure 1 -Research of the demand for public goods by fields of knowledge in Scopus database.

Analysis of scientific papers with the keywords "demand for public goods" by publications geography showed the highest presence of such works in the United States (40 items). Next ones are the United Kingdom and Germany with significantly lower rates - 5 and 4, respectively (Fig. 2). This indicates the interest of scientists in research on the demand for public goods in developed countries.

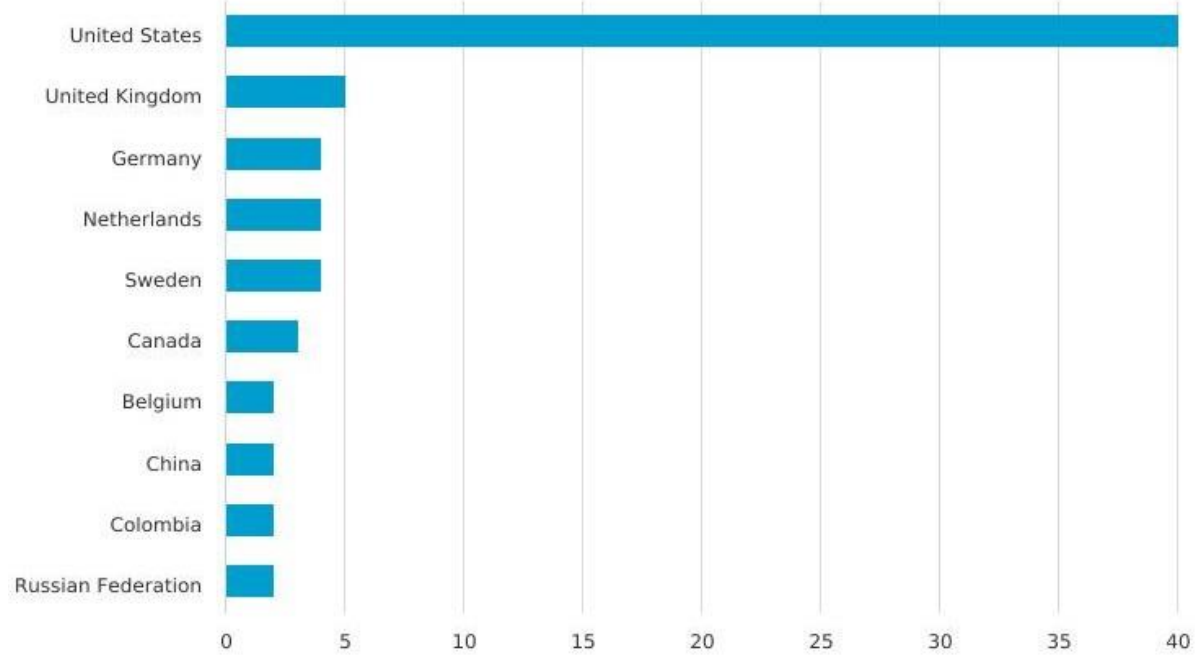

Figure 2 - Georgraphy of scientific papers devoted to the assessment of the demand for public goods (keywords search in Scopus database)

The list of authors who publish scientific papers with the keywords "demand for public goods" more often than others is presented in the figure 3: Bohm P. [4, 5], Isaak R. [6], Kurz M. [7], Toit-Brits C., Blignaut H. [8], Wang Z., Liu X. [9], Pangalila T., Tuerah J., Umar M. [10], Pospieszna P., Galus A. [11], Campbell D., Niemi R. [12], Almond G., Verba S. [13]. 


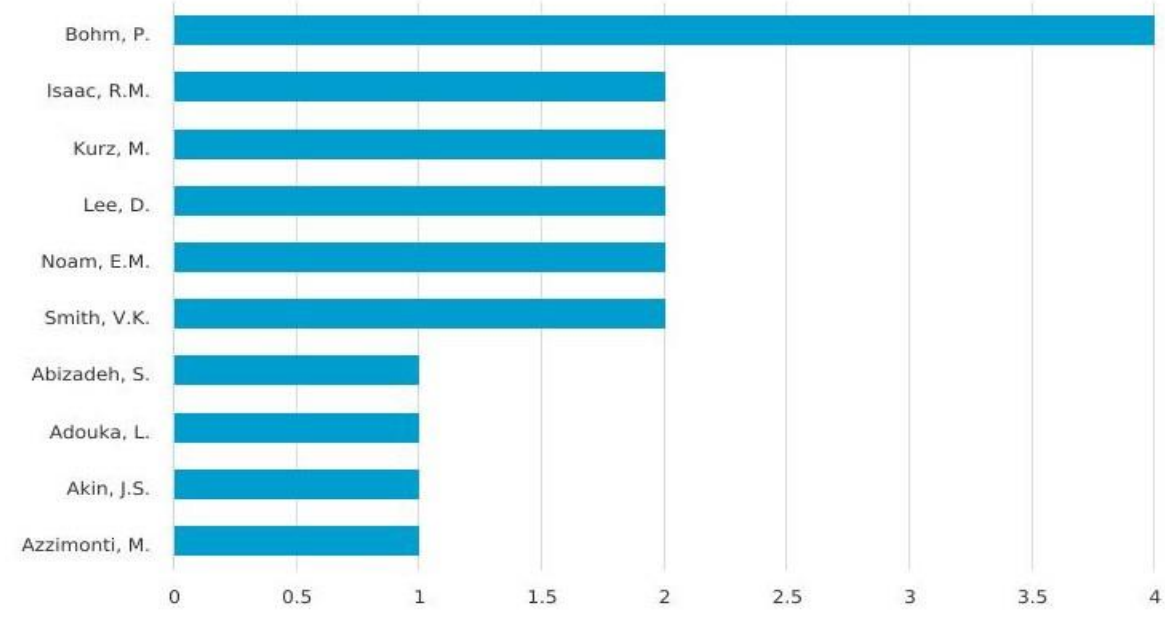

Figure 3 - Top 10 authors, whose works are devoted to research of the demand for public goods (results obtained in Scopus database)

In particular, P. Bohn focuses his attention on the mechanism of studying the demand for public goods [4]. R. Isaak proposes a mechanism by which, according to the author, you can increase or decrease the demand for public goods [6]. M. Kurz describes an experimental approach to determine the demand for public goods [7].

At the same time, approaches to the assessment of the demand for public goods of local significance have been little studied in the scientists works. Few scientific papers are devoted to the practice of assessment of the demand for public goods in the non-market sector of the economy.

\section{AIM OF THE PAPER}

The aim of the research is the assessment of the demand for civic education as a public good that is formed and consumed in the non-market sector of the economy.

\section{STATEMENT OF THE MAIN RESEARCH MATERIAL}

Civic education is a public good, which means the impossibility of forming a market price for this type of educational services. At the same time, civic education is important for local communities and society as a whole, as it ensures the effective functioning of social mechanisms.

If we give a brief definition of how we understand civic education in the context of research, it is the art of living successfully and happily in the community. Accordingly, there are institutions that provide the supply of civic education, which need to determine the need and demand for this good.

In our research we decided to investigate the process of forming and meeting the demand for civic education.

Object of research: the population of Sumy city (regional center in the north-eastern part of Ukraine). The total population of the city in 2018 - around 260 thousand inhabitants.

The objectives of our study:

1) assessment of civic competencies of the population of Sumy city and identification of current demand for civic education;

2) identification of contradictions between the demand and supply of civic education services;

3) formation of proposals to eliminate contradictions in demand and supply of civic 
education services and increase the effectiveness of civic education measures.

Research methods: desk research (analysis of publications, reviews, reports), qualitative research (focus groups, in-depth interviews), quantitative research (sociological survey).

Research hypotheses:

1) low demand for civic education in the conditions of absence of a high level of civic competence;

2) mismatch of supply and demand in the field of civic education.

The research was conducted in several stages:

1) preparatory stage (development of "design and composition" of research, tools).

2) conduction of desk research: analysis of publications, reviews, reports on civic education in the city.

3) qualitative research: focus groups and in-depth interviews with opinion leaders.

4) conduction of sociological survey to assess the key civic competencies of the population of Sumy city (propensity for civic participation, knowledge of rights and responsibilities, knowledge of the law, critical thinking, tolerance, etc.);

5 ) assessment of civic competencies in terms of reforms (reforms in the provision of municipal services, reforms in education, police, health care reforms);

6) analysis of the demand for civic education services;

7) analysis of the supply of civic education services (trainings, seminars, discussions on civic education);

8) analysis of contradictions between demand (needs) and supply of civic education services;

9) formation of recommendations based on the results of the study;

10) preparation of the publication.

To analyze the market of educational needs, a comparison was made between the requests of the population of Sumy city and data on the number of events held in Sumy city by providers of civic education services.

In the framework of this research, information on the activities carried out by each provider was collected and classified. The source of information was social networks, where videos and photo-reports about the events are posted.

As a result, each educational service gained value in two parameters: demand from the population, and the number of actual activities held.

The classification of educational events according to the types of services identified in the research was determined with the involvement of experts in civic education. 


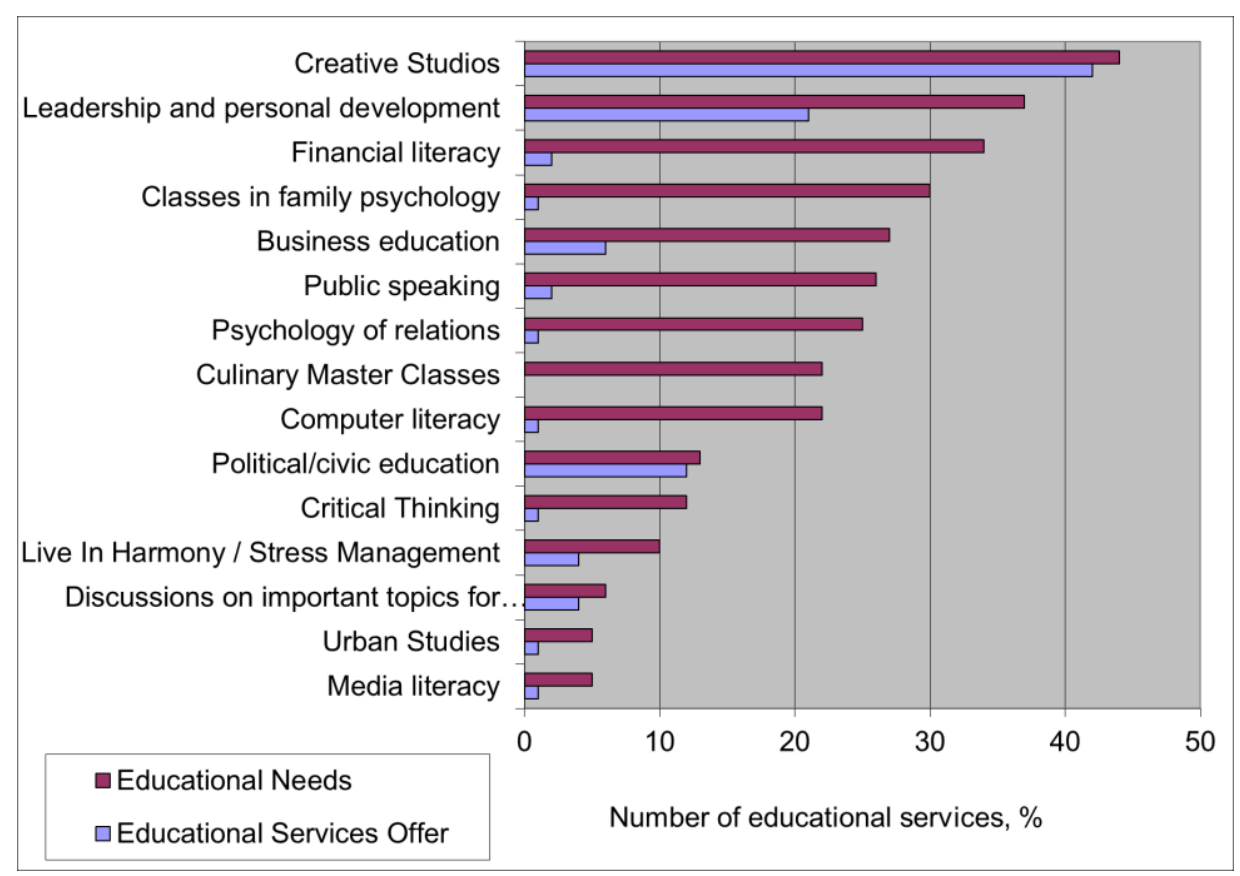

Figure 3 - Comparison of requests of the target audience and actual events held among civic education providers. Source: authors' calculation based on primary field research data (2018)

Regarding various areas of civic education, the results of the analysis showed that the greatest demand is for creative studios, and this demand is quite satisfied. Next in the ranking are educational services in the field of leadership and personal development, but these needs are met with less than half. The rest of the needs are unmet, and at the same time we see that due to the actions of service providers, the interest of citizens in political or civic education is approaching to satisfaction level. At the same time, low satisfaction of the needs in financial literacy, critical thinking, media literacy indicate the need to develop and offer educational services of this type.

At the same time, we believe it is necessary to conduct additional promotion and explanatory work to spread interest in political or civic education, which should include modules on critical thinking, media and computer literacy. The need for leadership services also intersects with the competencies of political or civic education course, as leadership development can and should take place through involvement in urban and regional community development initiatives.

Demand for family psychology studies, relationship psychology, public speaking and business education is unmet. In Sumy city there is a paid business school, several schools of public speaking and relationship psychology. According to the interviews, they do not feel a surplus in the audience.

A comparison of data on demand for educational services and data on the level of possible payment for services suggests that the target audience generally underestimates services in value terms, does not want to pay for courses, and the current high demand is due to the desire to receive these services for free or cheaper than they are offered in the market. One of the findings of the survey can be considered the identification of high interest of the population in culinary master classes.

In constant demand are civic education services provided by a well-known lecturer, trainer, a person who knows how to interest the audience, or services with quality content.

Data of the research actually confirmed the hypothesis of low demand for civic education in the conditions of absence of a high level of civic competence. 
In general, the comparison of the interest of respondents and the number of events which were actually held in Sumy city is conditional but quite acceptable method for understanding the dynamics of the educational services market. Results of the research allow to adjust plans of seminars, the content of classes to best meet the needs of citizens in educational services, taking into account local educational needs and trends.

\section{CONCLUSIONS}

1. Low demand for civic education in conditions of absence of a high level civic competence of citizens. In such circumstances, the order for civic education as a public good is formed by local authorities, but not local residents.

2. Mismatch of supply and demand in the field of civic education. For example: a large supply of trainings on gender equality in the absence of sufficient demand, a large demand for information and computer literacy with a low supply of non-formal education courses.

3. The discrepancy between the "discourses" of the population and civil activists as representatives of civil society (actualization of irrelevant problems and, accordingly, formation of erroneous signals about the demand for civic education). In such situation it is difficult to distinguish political populism and real efforts directed to solve local problems. Thus, in particular, the target function of many civil society activists who are bloggers is to increase the "likes" of their posts, but not to solve the problems of the local community.

4. In civic education courses, listeners do not believe in ideas, but specific people (successful civic education coaches themselves must be public figures). Therefore, the demand for civic education as a public good is transformed into demand for learning and communication with opinion leaders in society.

5. Absence of barriers to entry for new providers into the sector of civic education services. But the question arises about the quality of such services and the formation of a quality supply of civic education services. This is possible only in conditions of formation of effective demand from local authorities and local public institutions (local schools, universities, businesses, NGOs).

The article was published as part of research work 0120U102001 "Reforming the lifelong learning system in Ukraine to prevent labor emigration: a cooperative model of institutional partnership"

\section{REFERENCES}

1. Greenberg, R. S. Economic sociodynamics (2000). M.: ISEPRESS, pp. 1-436 [in Russian].

2. Dlugopolsky, O.V. Public sector of the economy and public finance in the era of global transformations: monograph (2011). Ternopil: Econ. opinion of TNEU, pp. 1-632. [in Ukrainian].

3. Musgrave, R. A. Provision for Social Goods. Public Economics. [J. Margolis, H. Guitton (Eds.)] (1969). London-Basingstoke, pp. 53-135.

4. Bohm, P. Chapter 79 Field-test Elicitations of Demand for Public Goods (2008). Handbook of Experimental Economics Results, 1 (C), pp. 736-741.

5. Bohm, P. Revealing demand for an actual public good (1984). Journal of Public Economics, 24 (2), pp. 135-151.

6. Isaac, R.M., Norton, D.A., Pevnitskaya, S. A new experimental mechanism to investigate polarized demands for public goods: the effects of censoring (2019). Experimental Economics, 22 (3), pp. 585-609.

7. Kurz, M. Experimental approach to the determination of the demand for public goods (1974). Journal of Public Economics, 3 (4), pp. 329-348.

8. Toit-Brits, C., Blignaut, H. Positioning self-directed continuing learning skills in twenty-first century education (2019). Tydskrif vir Geesteswetenskappe, 59 (4).

9. Wang, Z., Liu, X. Demands for Education and Health and the Desire for Social Mobility in Rural China: Perspectives on Weak Consumer Motivation (2019). SAGE Open, 9 (2).

10. Pangalila, T., Tuerah, J., Umar, M. Character formation through civic education learning process (2020) International Journal of Psychosocial Rehabilitation, 24 (2), pp. 2335-2345.

11. Pospieszna, P., Galus, A. Promoting active youth: evidence from Polish NGO's civic education programme in Eastern Europe (2020). Journal of International Relations and Development, 23 (1), pp. 210-236.

12. Campbell, D.E., Niemi, R.G. Testing civics: State-level civic education requirements and political knowledge (2016). American Political Science Review, 110 (3), pp. 495-511.

13. Almond, G.A., Verba, S. The civic culture: Political attitudes and democracy in five nations (2015). The Civic Culture: Political Attitudes and Democracy in Five Nations, pp. 1-562. 


\section{REFERENCES (in original language)}

1. Гринберг, Р. С. Экономическая социодинамика. М. : ИСЭПРЕСС, 2000. 436 с.

2.Длугопольський, О.В. Суспільний сектор економіки і публічні фінанси в епоху глобальних трансформацій : моногр. Тернопіль : Екон. думка ТНЕУ, 2011. 632 с.

3. Musgrave, R. A. Provision for Social Goods. Public Economics. [J. Margolis, H. Guitton (Eds.)]. LondonBasingstoke, 1969.

4. Bohm, P. Chapter 79 Field-test Elicitations of Demand for Public Goods (2008). Handbook of Experimental Economics Results, 1 (C), pp. 736-741.

5. Bohm, P. Revealing demand for an actual public good (1984). Journal of Public Economics, 24 (2), pp. $135-151$.

6. Isaac, R.M., Norton, D.A., Pevnitskaya, S. A new experimental mechanism to investigate polarized demands for public goods: the effects of censoring (2019). Experimental Economics, 22 (3), pp. 585-609.

7. Kurz, M. Experimental approach to the determination of the demand for public goods (1974). Journal of Public Economics, 3 (4), pp. 329-348.

8. Toit-Brits, C., Blignaut, H. Positioning self-directed continuing learning skills in twenty-first century education (2019). Tydskrif vir Geesteswetenskappe, 59 (4)

9. Wang, Z., Liu, X. Demands for Education and Health and the Desire for Social Mobility in Rural China: Perspectives on Weak Consumer Motivation (2019). SAGE Open, 9 (2).

10. Pangalila, T., Tuerah, J., Umar, M. Character formation through civic education learning process (2020) International Journal of Psychosocial Rehabilitation, 24 (2), pp. 2335-2345.

11. Pospieszna, P., Galus, A. Promoting active youth: evidence from Polish NGO's civic education programme in Eastern Europe (2020). Journal of International Relations and Development, 23 (1), pp. 210-236.

12. Campbell, D.E., Niemi, R.G. Testing civics: State-level civic education requirements and political knowledge (2016). American Political Science Review, 110 (3), pp.495-511.

13. Almond, G.A., Verba, S. The civic culture: Political attitudes and democracy in five nations (2015). The Civic Culture: Political Attitudes and Democracy in Five Nations, pp. 1-562.

\section{АНОТАЦІЯ}

Петрушенко Ю., Майборода Т., Онопріснко К. Оцінка попиту на суспільні блага в секторі неринкових послуг

Стаття присвячена розробці та апробації підходів до оцінки попиту на суспільні блага. $B$ ній наведено результати оцінки попиту на громадянську освіту як суспільне благо сектору неринкових послуг. Проведена оиінка грунтується на застосуванні різних дослідницьких методів: кабінетного дослідження (аналіз публікацій, оглядів, звітів), якісного дослідження (фокус-групи, глибинні інтерв'ю), кількісного дослідження (соиіологічне опитування). У роботі проведено бібліометричний аналіз наукових публікацій, присвячених аналізу попиту на суспільні блага, виділено актуальні аспекти досліджень.

Об'єктом дослідження є прочес формування $i$ задоволення попиту на громадянську освіту. Для аналізу ринку освітніх потреб було зроблено співставлення запитів населення на освітні послуги та даних про кількість проведених заходів провайдерами освітніх послуг.

Результатом дослідження є доведення гіпотез щуодо низького попиту на громадянську освіту в умовах відсутності високого рівня громадянських компетентностей та невідповідності попиту $i$ пропозииії в сфері громадянської освіти.

Щодо різних напрямів громадянської освіти, то результати аналізу засвідчили те, щзо найбільшим попитом користуються творчі студії, $і$ цей попит є досить задоволеним. Наступні за рейтингом $є$ освітні послуги у сфері лідерства та власного розвитку, але задоволеність в цих потребах менша майже в половину. Решта потреб є незадоволеними, і в той же час ми бачимо, щзо завдяки діям провайдерів послуг иікавість містян у політичній або громадянській освіті наближається до задоволення. В той же час, низька задоволеність потреб у фінансовій грамотності, критичному мисленні, медійній грамотності вказують на необхідність розроблення та пропозиції освітніх послуг цьього типу. Незадоволеним є також попит на заняття із сімейної психологї, психології стосунків, ораторського мистеитва та бізнес-освіти.

У висновках дослідження сформульовані пропозиціі щзодо узгодження попиту $i$ пропозииї на громадянську освіту за допомогою неринкових механізмів. Зокрема, обтрунтовано необхідність формування ефективного попиту з боку місцевої влади та місцевих суспільних інститутів (місцевих шкіл, університетів, бізнесу, громадських організацій).

Ключові слова: суспільні блага, неринкові послуги, попит, пропозиція, громадянська освіта. 